\title{
REPELLENCY OF CELERY ESSENTIAL OILS (Apium graveolens L.) AGAINST Spodoptera frugiperda (Lepidoptera: Noctuidae) IN THE LABORATORY
}

\author{
Trisnani Alif \& Fita Fitriatul Wahidah \\ Department of Biology, Faculty of Mathematic and Natural Scince, Universitas Billfath, Indonesia \\ J1. Yayasan Pondok Pesantren Al Fattah Lamongan Jawa Timur 62271 \\ E-mail: trisnanialif@billfath.ac.id
}

Manuscript received: 22 November 2020. Revision accepted: 14 April 2021.

\begin{abstract}
Repellency of celery essential oil (Apium graveolens L.) against Spodoptera frugiperda (Lepidoptera: Noctuidae) in the laboratory. Essential oil is one of the ingredients that has repellent ability to herbivorous insects. Celery is one of plants containing essential oil which may also have the repellent ability. This study was aimed to determine the differences in the repellent ability of celery essential oils compounds that were taken from 3 different locations against $S$. frugiperda in the laboratory. This research was arranged in a factorial completely randomized design (CRD) with two factors. The first factor was the origin of the celery plants (Malang, Surabaya, and Lamongan) and the second factor was the concentration level of essential oils $(1000,2000$, and 3000 ppm) which was repeated three times. The reliability test was carried out using filter paper method. The results showed that the essential oil extracted from celery originated from Malang with 3000 ppm concentration had the highest percentage level of repellency (level 5) that reached $93.33 \%$ of repellency. Location and concentration factors had no different effect on $S$. frugiperda larvae repellency. There was no correlation between location and concentration on the repellency of $S$. frugiperda larvae.
\end{abstract}

Key words: concentration, filter paper method, interaction, larvae, repellent

\section{INTRODUCTION}

Spodoptera frugiperda (Lepidoptera: Noctuidae) is one of the important insect pests of maize in Indonesia. S. frugiperda was first reported in West Sumatra on March 2019 (FAO, 2019). Subsequently, it was reported in Bengkulu, Lampung and West Java (Ginting et al., 2020; Trisyono et al., 2019; Maharani et al., 2019). The damage caused by this pest could reached $100 \%$ in young maize plant (Trisyono et al., 2019). Currently, application of chemical pesticides is the main alternatives used by farmers in Lamongan, East Java for controlling pest insects, including $S$. frugiperda. Chemical pesticides contain toxic and hazardous chemicals as well as persistent organic pollutants that have a negative impact on human health and the environment.

Environmentally friendly control technology using organic plant materials is an alternative that has the potential to be developed. Organic plant materials that provide direct activity against the target organism are known as botanical pesticides. Some of the advantages of plant-based pesticides such as having unique mode of action, not toxic to mammals, easily decompose in nature so it does not pollute the environment and relatively safe for humans and pets because it has easily degraded residue, the materials can be easily found in nature, and relatively easy to make (Asmaliyah et al., 2010).

Several studies reported that various types of plants could play a role as botanical pesticides. Application of lemongrass oil with a concentration of $5 \mathrm{~mL} \mathrm{~L}^{-1}$ on pepper in Bangka could reduce the population and yield loss due to Dasynus piperis (Rohimatun \& Laba, 2013). The application of plant extract of billygoatweed (Ageratum conyzoides), ginger (Zingiber officinale), galangal (Alpinia malaccensis), pinecone ginger (Z. zerumbet), gotu kola (Centella asiatica), lemongrass (Cymbopogon nardus), physic nut (Jatropha curcas), and turmeric (Curcuma longa) at a concentration of $5 \mathrm{~mL} \mathrm{~L}^{-1}$ causing mortality of rhizome flies (Mimegralla coeruleifrons) for more than $80 \%$ (Balfas et al., 2013). Spraying directly with $0.5 \%$ of plant extract of $C$. longa, A. conyzoides, C. nardus and Syzygium aromaticum (cloves) oil resulted in mortality of more than $80 \%$ of rhizome flies (M. coeruleifrons). The application of plant extract of neem and lemongrass to ginger showed ability to reduce 
the population of $M$. coeruleifrons by $90 \%$ and $60 \%$, respectively as well as reducing the number of eggs of M. coeruleifrons (Balfas \& Sugandi, 2013).

Celery (Apium graveolens L.) is a plant that has potential as a botanical pesticide. This plant has a high content of active chemical compounds that is toxic to pest insects. Celery leaf extract has been reported as a contact pesticide and insect repellent (Tuetun et al., 2005; Kooti \& Daraei, 2017; Astuti \& Khotimah, 2020). Celery leaf extract has also been reported to be able to inhibit egg laying (antioviposition) of bean beetle (Callosobruchus chinensis L.; Coleoptera: Bruchidae) (Darmiati, 2013). To date, there is still no information on the ability of the celery essential oil as repellent for $S$. frugiperda. This study was aimed to determine the repellency of the celery essential oils to $S$. frugiperda.

\section{MATERIALS AND METHODS}

Research Site. The research was carried out from May to November 2020. Celery plant samples were taken in three districts with different altitude, namely
Malang (1100 masl 7³1'S; $\left.111^{\circ} 40^{\prime} \mathrm{E}\right)$, Surabaya (25 masl, 7²1'S; 112 54'E) and Lamongan (11 masl, $7^{\circ} 11^{\prime} \mathrm{S} ; 112^{\circ} 14 \mathrm{E}$ ) (Figure 1). Repellency ability test of celery essential oils towards $S$. frugiperda was conducted at the Biology Laboratory, Universitas Billfath.

Celery Leaves Sampling. The determination of the sampling plot for celery leaf collection in each district was carried out using a purposive sampling method. Observations were made directly on the existence of celery plants in each selected district. Sampling was carried out using a line transect with a length of $110 \mathrm{~m}$, measured using a rolling meter, then divided into 4 plots measuring $20 \times 20 \mathrm{~m}$. At each observation location 5 line transects were placed. Leaf samples were taken from the first to third leaflets, then cut, packed in plastic, labeled, and stored in a Styrofoam box $(34 \times 25 \times 230$ $\mathrm{cm})$ with ice pack to keep the celery leaves fresh until extraction.

Insect Collection. The $S$. frugiperda was obtained from farmer's maize in Lamongan (Figure 2). In total,

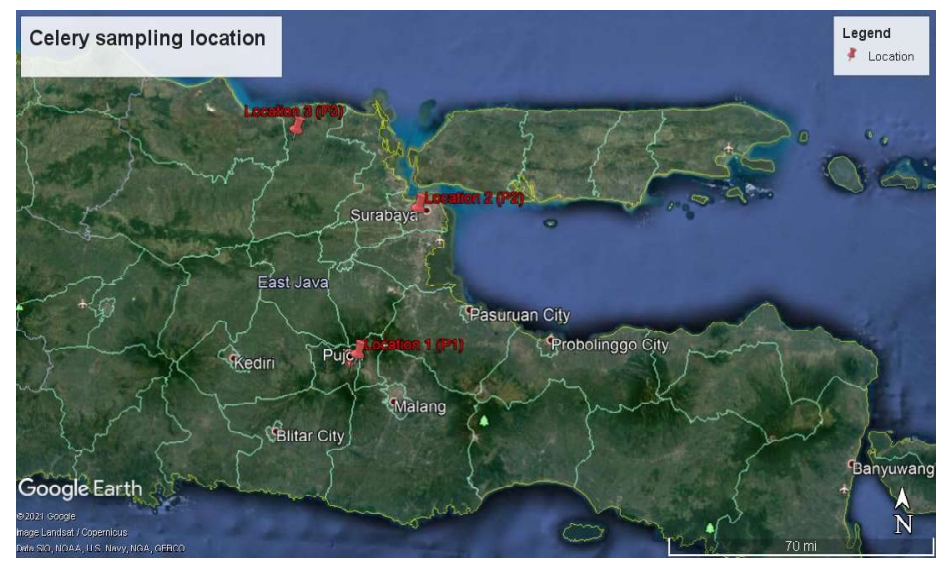

Figure 1. Celery sampling location map.

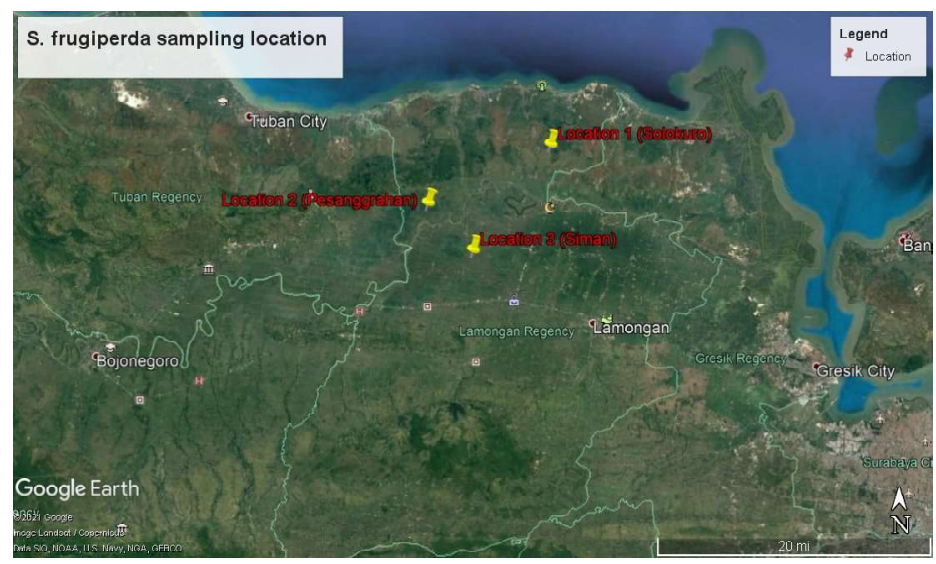

Figure 2. S. frugiperda sampling location map. 
$2703^{\text {rd }}$ instar larvae of $S$. frugiperda were taken and transported to the laboratory.

Essential Oil Extraction. The essential oil was extracted using the maceration method. Each fresh leaf was weighed $100 \mathrm{~g}$ with the analytical balance ATX224 to 0.01 accuracy (Shimadzu, Japan). The leaves were chopped and soaked in N-hexane pro analysis (P.A) solvent with a ratio of $1: 10$. The solution then stirred manually every $24 \mathrm{~h}$ and kept at room temperature without light exposure (in a closed and dark place) for 3 days. Then the extract was separated by filtering using filter paper and squeezed so that the pulp and filtrate were obtained. The filtrate containing oil was evaporated using a rotary vacuum evaporator at a temperature of $65-70{ }^{\circ} \mathrm{C}$, to separate the solvent from the essential oil. The filtrate was stored in the refrigerator for $24 \mathrm{~h}$ to precipitate the wax. The oil on the top layer was then separated from the settling wax with a separating funnel to obtain the essential oil.

\section{Repellency Effect of Essential Oils towards} S. fungiperda. This study used a factorial completely randomized design (CRD) method with 2 factors and 3 replications. Factor 1: the location of celery essential oil sampling, namely, Malang (K1), Surabaya (K2) and Lamongan (K3). Factor 2: the level of essential oil concentration consists of $1000 \mathrm{ppm}(\mathrm{P} 1), 2000 \mathrm{ppm}(\mathrm{P} 2)$ and $3000 \mathrm{ppm}(\mathrm{P} 3)$. The method referred to Hasyim et al. (2014) with modification. Investigation was carried out using the filter paper method. Each filter paper (Whatman no. 1;22 cm of diameter) was divided into two parts. One part was dripped with celery essential oil another part was dripped by water as a control. The filter paper then dried and placed in a petri dish $(15 \mathrm{~cm}$ of diameter). A total of $103^{\text {rd }}$ instar larvae of $S$. frugiperda were placed in the middle of a petri dish filled with both treated and untreated filter paper. Observations were conducted at 1, 3, 6, and $24 \mathrm{~h}$ after treatment. The responses of $S$. frugiperda was calculated using the formula described by Hasyim et al. (2014):

$$
\mathrm{R}=\frac{\mathrm{NC}-\mathrm{NT}}{\mathrm{NT}+\mathrm{NC}} \times 100 \%
$$

$\mathrm{R}=$ response of $S$. frugiperda

$\mathrm{NC}=$ number of $S$. frugiperda larvae contained in the control

NT $=$ number of $S$. frugiperda larvae contained in the treatment
To determine the level of response, the following criteria were used (Hasyim et al., 2014):

$0=$ Repellency value $<0.1$

$1=$ Repellency value $0.1-20.0 \%$

$2=$ Repellency value $20.1-40.0 \%$

$3=$ Repellency value $40.1-60.0 \%$

$4=$ Repellency value $60.1-80.0 \%$

$5=$ Repellency value $80.1-100 \%$

Data Analysis. The data were analyzed using ANOVA followed by the Duncan Multiple Range Test (DMRT) at the $5 \%$ of significant level.

\section{RESULTS AND DISCUSSION}

The results showed that at 24 hours after treatment, most of $S$. frugiperda larvae moved to the untreated filter paper (Figure 3). This might be due to the repellent compound that is contained in the celery leaves. The celery essential oil contain D-limonene, D-selinene, Sedanolide, Terpineol, Santalol, Selinene, Nerolidol, $\beta$ pinene, dan $\beta$ myrcene (Al-Asmari et al., 2017). The $D$-limonene compound is an insecticide which acted as repellent (Luik et al., 1999). The essential oils compound mode of action is by interact with the larva olfactory receptors and blocking the sense of smell (Tripathi et al., 2009). The celery produced strong odor which will repel the larvae of $S$. frugiperda.

The analysis of variance result showed that the sampling location and concentration of celery essential oil had no different effect on the repellency of S. frugiperda larvae (Table 1). There was no correlation between sampling location and concentration of celery essential oil on the repellency of $S$. frugiperda larvae. Based on the altitude, the location of Malang has the highest level of altitude, its 1100 masl, then Surabaya 25 masl and Lamongan has the lowest altitude level of 11 masl. Table 1 showed that the highest repellency (level 5) was showed in the treatment of celery essential oil collected from Malang Regency with a concentration of $3000 \mathrm{ppm}$ with the average value of response was up to $93.33 \%$. The lowest repellency (level 3) was observed in the treatment of celery essential oil obtained from Lamongan at a concentration of $1000 \mathrm{ppm}$ with the average value of response was up to $53.33 \%$.

Celery essential oil from Malang had the higher response value when compared to the essential oil from Surabaya and Lamongan. It was possible to the differences in the chemical compound concentration which was responsible on the repellent activity. Azkiyah \& Tohari (2019) reported that altitude had significantly correlated with air temperature and chemical content 


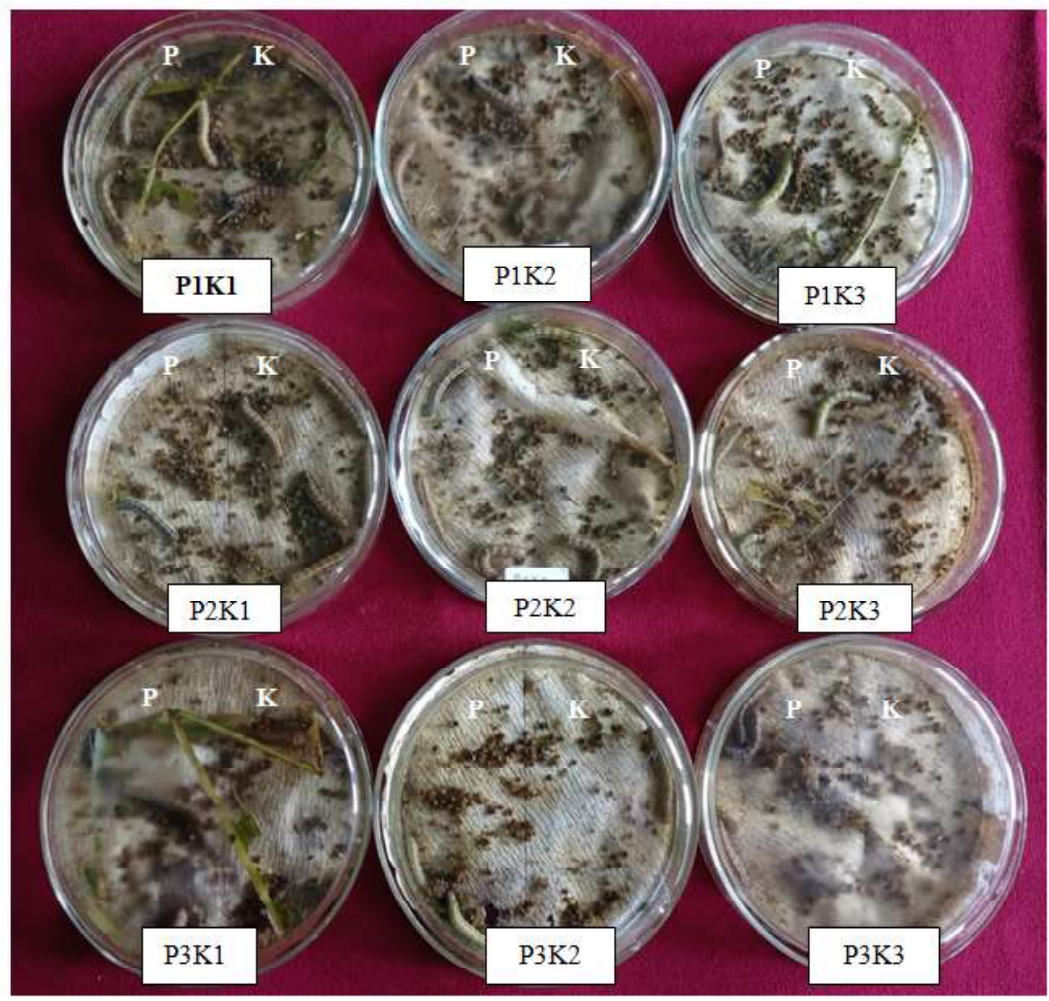

Figure 3. Observation results of $S$. frugiperda resistance testing after 24 hours. $\mathrm{P}=$ Treatment; $\mathrm{K}=\mathrm{Control}$; $\mathrm{P} 1 \mathrm{~K} 1=$ Malang treatment with a concentration of $1000 \mathrm{ppm} ; \mathrm{P} 1 \mathrm{~K} 2=$ Malang treatment with a concentration of $2000 \mathrm{ppm} ; \mathrm{P} 1 \mathrm{~K} 3=$ Malang treatment with a concentration of $3000 \mathrm{ppm} ; \mathrm{P} 2 \mathrm{~K} 1=$ Surabaya treatment concentration of $1000 \mathrm{ppm} ; \mathrm{P} 2 \mathrm{~K} 2$ = Surabaya treatment concentration of $2000 \mathrm{ppm} ; \mathrm{P} 2 \mathrm{~K} 3=$ Surabaya treatment concentration of $3000 \mathrm{ppm}$; P3K $1=$ Lamongan treatment concentration of $1000 \mathrm{ppm}$; P3K2 = Lamongan treatment with a concentration of $2000 \mathrm{ppm} ; \mathrm{P} 3 \mathrm{~K} 3=$ Lamongan treatment with a concentration of $3000 \mathrm{ppm}$

Table 1 . The percentage and level of essential oil repellency to $3^{\text {rd }}$ instar larvae $S$. frugiperda after $24 \mathrm{~h}$

\begin{tabular}{|c|c|c|c|}
\hline Treatment of essential oil & $\begin{array}{l}\text { The percentage of } \\
\text { repellency }(\%)\end{array}$ & $\begin{array}{l}\text { Level of } \\
\text { response }\end{array}$ & Altitude \\
\hline Malang 1000 ppm (P1K1) & 66.67 & 4 & 1100 masl $7^{\circ} 31^{\prime} \mathrm{S} ; 111^{\circ} 40^{\prime} \mathrm{E}$ \\
\hline Malang 2000 ppm (P1K2) & 76.67 & 4 & \\
\hline Malang 3000 ppm (P1K3) & 93.33 & 5 & \\
\hline Surabaya 1000 ppm (P2K1) & 80.00 & 4 & 25 masl, $7^{\circ} 21^{\prime} \mathrm{S} ; 112^{\circ} 54^{\prime} \mathrm{E}$ \\
\hline Surabaya 2000 ppm (P2K2) & 76.67 & 4 & \\
\hline Surabaya 3000 ppm (P2K3) & 66.67 & 4 & \\
\hline Lamongan 1000 ppm (P3K1) & 53.33 & 3 & $11 \operatorname{masl}, 7^{\circ} 11^{\prime} \mathrm{S} ; 112^{\circ} 14 \mathrm{E}$ \\
\hline Lamongan 2000 ppm (P3K2) & 66.67 & 4 & \\
\hline Lamongan 3000 ppm (P3K3) & 73.33 & 4 & \\
\hline
\end{tabular}

(total compound of stevioside and ratio of rebaudiosida $\mathrm{A} /$ steviosida) in Stevia rebaudiana plants. The chemical content of $C$. manga rhizome essential oil which was originated from lowlands had more concentration than it was from the highlands. The phenomenon was occurred because of the lower rainfall in the lowlands than the highlands (Astuti et al., 2014). Irrigation and harvesting time were also took effect on the content and composition of essential oils in celery. The irrigation could increase concentration of volatile substances of 
celery compared to the unirrigated one. In Poland, celery that had been harvested in September (using irrigation system) contained more limonene than in October (without any irrigation system) (Rozek et al., 2016).

The concentration of celery essentials oil also affected the larval repellency rate. The higher concentration would increase larval repellency level. Akuba et al. (2019) reported that celery methanol extract at the highest concentration $(15 \%)$ showed optimally killed mosquito larvae. The zodea leaf extract with the highest concentration $(45.87 \%)$ could reject Tribolium castaneum up to $96.2 \%$ (Cameron et al., 2016). The botanical insecticides of Babadotan were more effective to control $S$. litura at $500 \mathrm{~g} \mathrm{~L}^{-1}$ than $250 \mathrm{~g} \mathrm{~L}^{-1}$ (Sari et al., 2013).

\section{CONCLUSION}

Celery essential oil has the potential as a repellent against the S. frungiperda. The highest level of repellency from Malang with concentration $3000 \mathrm{ppm}$, and the lowest repellency from Lamongan with concentration $1000 \mathrm{ppm}$, and there is no correlation between the location and the concentration againt repellency of larvae.

\section{ACKNOWLEDGMENTS}

We would like to thanks to maize farmers in Lamongan, the celery planters in Lamongan, Surabaya and Malang for allowing us to do this research.

\section{REFERENCES}

Akuba J, Thomas N, \& Palay RDJ. 2019. Efek ekstrak metanol daun seledri (Apium graveolens Linn.) sebagai insektisida terhadap nyamuk. JSSCR. 1(1): 1-7.

Al-Asmari AK, Athar MdT, \& Kadasah SG. 2017. An updated phytopharmacological review on medicinal plant of Arab Region: Apium graveolens Linn. Pharmacogn Rev. 11(21): 1318.

Asmaliyah, Hadi EEW, Utami S, Mulyadi K, Yudhistira, \& Sari FW. 2010. Introduction of Vegetable Pesticide Producing Plants and their Traditional Use. Pusat Litbang Produktivitas Hutan. Palembang.
Astuti E, Sunarminingsih R, Jenie UA, Mubarika S, \& Sismindari. 2014. Pengaruh lokasi tumbuh, umur tanaman dan variasi jenis destilasi terhadap komposisi senyawa minyak atsiri rimpang Curcuma mangga produksi beberapa sentra di Yogyakarta. J. Manusia dan Lingkungan. 21(3): 323-330.

Astuti RD \& Khotimah S. 2020. Patch formulation of celery leaves extract (Apium Graveolens L.) as mosquito repellent. Advances in Social Science, Education and Humanities Research. 521: 8387.

Azkiyah DR \& Tohari. 2019. Effect of altitude on growth, yield and steviol glycosides content of stevia plant (Stevia rebaudiana). Vegetalika. 8(1): 1-12.

Balfas R \& Sugandi E. 2013. Effect of vegetable oil on Aspidiella hartii infestation on ginger. In: Otih R, Agus W, Nurliani B, Dono W, Supriadi, Laba IW, Rodiah B, Muhammad D, Hoerudin, Kannan S, Anandaraj M, Oriel FDL, \& Bui CB (Eds.). Prosiding Seminar Inovasi Tanaman Atsiri. pp. 86-96. Indonesian Agency for Agricultural Research and Development (IAARD), Solok.

Balfas R, Willis M, \& Sugandi E. 2013. Potential of botanical insecticides for controlling rhizome fly (Mimegralla coeruleifrons Macquart) on ginger. In: Otih R, Agus W, Nurliani B, Dono W, Supriadi, Laba IW, Rodiah B, Muhammad D, Hoerudin, Kannan S, Anandaraj M, Oriel FDL, \& Bui CB (Eds.). Proceedings of the International Seminar on Spices, Medicinal, and Aromatic Plants (SMAPS). pp. 153-157. Indonesian Agency for Agricultural Research and Development (IAARD), Jakarta.

Cameron RR, Arinafril, \& Mulawarman. 2016. Uji bioaktivitas ekstrak daun zodea (Evodia suaveolens Sheff) terhadap hama gudang Tribolium castaneum (Coleoptera: Tenebrionidae) Herbst. E-Jurnal Agroekoteknologi Tropika. 5(3): 222-231.

Darmiati NN. 2013. Uji aktivitas ekstrak daun seledri (Apium graveolens L.) terhadap kumbang kacang Callosobruchus chinensis L. (Coleoptera: Bruchidae). Agrotop. 3(1): 17-22. 
FAO. 2019. Indonesia Prepares for Battle with Fall Armyworm. http://www.fao.org/indonesia/news/ detail-events/en/c/1202177/. Accessed on November 2020.

Ginting S, Nadrawati, Zarkani A, \& Sumarni T. 2020. Natural incidence of entomopathogenic fungus Nomuraea rileyi on Spodoptera frugiperda infesting corn in Bengkulu. J. HPT Tropika. 20(2): 85-91.

Hasyim A, Setiawati W, Jayanti H, \& Krestini EH. 2014. Repellency of essential oils against of shallot stored insect Ephestia cautella (Walker) (Lepidoptera: Pyrallidae) under laboratory condition. J. Hort. 24(4): 336-345.

Luik A, Ochsner P, \& Jensen TS. 1999. Olfactory responsees of seed wasps Megastigmus pinus Parfitt and Megastigmus rafni Hoffmeyer (Hym., Torymidae) to host-tree odours and some monoterpenes. J. Appl. Entomol. 123(9): 561567.

Kooti W \& Daraei N. 2017. A review of the antioxidant activity of celery (Apium graveolens L). J. Evid. Based Complementary Altern. Med. 22(4): 1029-1034.

Maharani Y, Dewi VK, Puspasari LT, Rizkie L, Hidayat Y, \& Dono D. 2019. Cases of fall army worm Spodoptera frugiperda J. E. Smith (Lepidoptera: Noctuidae) attack on maize in Bandung, Garut and Sumedang District, West Java. J. Cropsaver. 2(1): 38-46.
Rohimatun \& Laba IW. 2013. Efektivitas insektisida minyak serai wangi dan cengkeh terhadap hama pengisap buah lada (Dasynus piperis China). Bul. Littro. 24(1): 26-34.

Rozek E, Nurzyñska-Wierdak R, Salata A, \& Gumiela P. 2016. The chemical composition of the essential oil of leaf celery (Apium graveolens L. Var. Secalinum Alef.) under the plants' irrigation and harvesting method. Acta Sci. Pol. Hortorum Cultus. 15(1): 149-159.

Sari M, Lubis L, \& Pangestiningsih Y. 2013. Uji efektivitas beberapa insektisida nabati untuk mengendalikan ulat grayak (Spodoptera litura F.) (Lepidoptera: Noctuidae) di laboratorium. $J$. Online Agroekoteknologi. 1(3): 560-569.

Tripathi AK, Upadhyay S, Bhuiyan M, \& Bhattacharya PR. 2009. A review on prospects of essential oils as biopesticide in insect-pest management. J. Pharmacogn. Phytotherapy. 1(5): 52-63.

Trisyono YA, Suputa, Aryuwandari VEF, Hartaman M, \& Jumari. 2019. Occurrence of heavy infestation by the fall armyworm Spodoptera frugiperda, a new alien invasive pest, in corn in Lampung Indonesia. JPTI. 23(1): 156-160.

Tuetun B, Choochote W, Rattanachanpichai E, Chaithong U, Chaiwong P, Jitpakdi A, Tippawangkosol P, Riyong D, \& Pitasawat B. 2005. Repellent properties of celery, Apium graveolens L., compared with commercial repellents, against mosquitoes under laboratory and field conditions. Trop. Med. Int. Health. 10(11): 1190-1198. 